tolerated by many individuals, this does not remove these from the ambit of our theory. Indeed, a tentative connection between committment to symbiotic microbes and sexual selection is indicated in a variety of disparate taxa from anelgesid mites to ruminant ungulates ${ }^{8}$.

We also join Cox in hoping that the 'phylogenetic relationship' found by Read and Harvey ('association' in their terms) will be followed up. Its slant is consistent in the studies carried out and suggests to us the following possibilities in accord with our thesis: first, parasites bring high sexual selection, and this, through stringent mate choice, encourages speciation ${ }^{4-11}$; second, non-conforming trends (costly sexual selection with no payoff to descendants' health, or no sexual selection when parasites are damaging) reduce species survival.

Department of Zoology,

W. D. HAMILTON

South Parks Road,

Oxford OX1 3PS, UK

Department of Biology,

University of New Mexico,

Albuquerque, New Mexico 87131, USA

1. Read, A.F. \& Hanvey, P.H. Nature 340, 105 (1989).

2. Zuk, M. Nature 340, 104-105 (1989).

3. Hamilton, W.D. \& Zuk, M. Science 218, 384-387 (1982).

4. Read, A.F. \& Harvey, P.H. Nature 339, 618-620 (1989)

5. Read, A. Nature 327, 68-70 (1987).

6. Bennett, G.F., Caines, J.R. \& Bishop, M.A. J. Wildl. Dis 24, 339-343 (1988)

Ewald. PW Oxford Surv evol. Biol 5, 215-245 (1988)

8. Hamilton, W. D. Am Zool (in the press)

8. Hamilon, W.D. Am Zool (in the press). Echelle. A.A. \& Kornfield, L.) 231-249 (University of Maine, Orono, 1983)

10. Lande, R. \& Kirkpatrick, M. J. theor. Biol. 133, 85-98 (1988)

11. Carson. H.L., Kaneshiro, K.Y. \& Val, F.C. Evolution 43 190-203 (1989).

\section{Armenian earthquakes}

SIR-A recent report' on the 1988 Armenian earthquake raises important issues concerning earthquake hazard and tectonic deformation rate in this region. The figure shows part of its fault scarp, indicating what seems to be an older Holocene scarp sub-parallel to it. Assuming that the local soil formed near the end of the Pleistocene glaciation $(\sim 10,000$ years ago,) the estimated recurrence interval of major earthquakes on this fault is about 5.000 years or more, and the 2 -m Holocene throw implies an average slip rate of $\sim 0.2 \mathrm{~mm} \mathrm{yr}$ or less. The 1988 earthquake occurred on one of a set of parallel reverse faults with ESE strike, some of which had been identified previously ${ }^{2}$, that take up shortening across Armenia and the adjacent Soviet Transcaucasian republics. The largest known historical earthquake in what is now Soviet Transcaucasia occurred in 1668 near Shemakhat ${ }^{+-6}$, now in
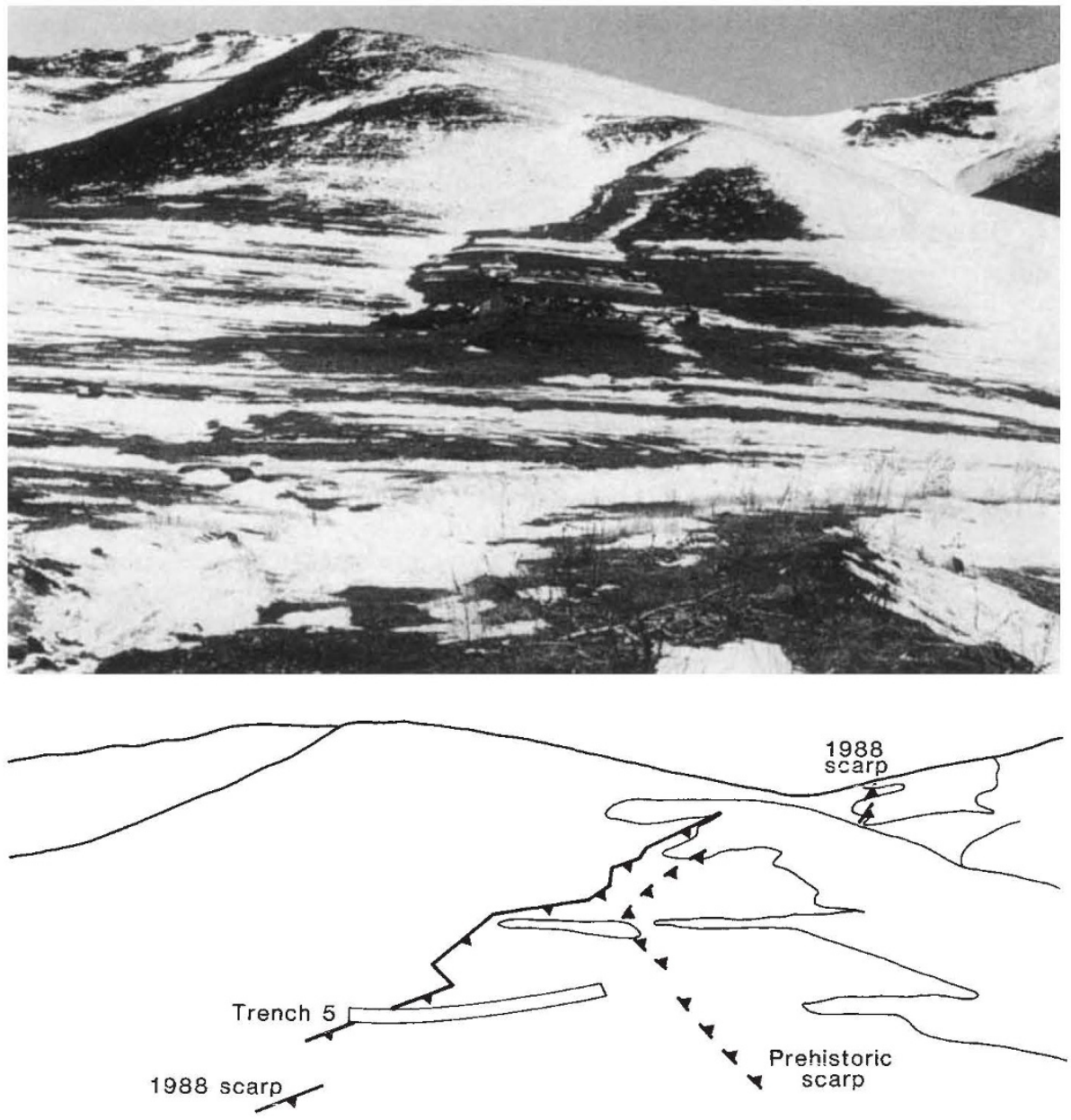

The view looking WNW from latitude $40^{\prime} 49.9^{\prime} \mathrm{N}$ longitude $44^{\prime} 13.1^{\prime} \mathrm{E}$ showing, highlighted by shallow snowdrifts, the 1988 fault scarp at $\sim 1,900$-m elevation, $\sim 500 \mathrm{~m}$ east of its highest point, and the suggested older scarp up to 10-m farther north to its right, both with $\sim 1$-m reverse throw. Both scarps can be followed along strike for $\sim 500 \mathrm{~m}$ in soil that is probably late glacial or early post-glacial ( 10,000-yr old), given the presence of moraine deposits and glacial cirques at similar elevation nearby. The arid climate and the absence of local soil disturbance by agriculture (in contrast with lower elevations) favour scarp preservation. The abrupt 1988 scarp has been trenched, but the trench stops $\sim 2-m$ short of the other, more rounded, scarp. It is hoped that this trench will be extended northward and radiocarbon dating of samples from it will provide quantitative constraint on the Holocene slip history suggested for this fault. Both scarps probably merge into the same active reverse fault at a few tens of metres depth, which dips NNE (to the right) at $\sim 60^{\prime}$. The photograph was taken in February 1989. The sketch shows an interpretation, with chevron markers indicating the hanging walls of both scarps which are uplifted relative to the footwalls.

Soviet Azerbaijan. The $\sim 50-\mathrm{km}$ WNWESE extent of severe damage, more than in 1988 indicates $M_{4}$ (surface-wave magnitude $) \simeq 7$. Including the 1988 event $\left(M_{\mathrm{s}}=\right.$ 6.7) only five Transcaucasian earthquakes in the past 1,200 years, or so, are known to have caused damage equivalent to $M$ 6.5-7 (ref. 6). Co-seismic slip rate on other individual faults must, therefore also be very low, and the shortening rate across Transcaucasia can be no more than a few millimetres a year ${ }^{7}$. Nonetheless, it seems prudent to base regional earthquake hazard planning on the assumption that an earthquake with $M \geqslant 7$ may occur on any of these faults, with a probable recurrence interval for such events on any individual fault of many thousands of years. Furthermore, the suggested low regional deformation rate means that many geomorphological features such as river terraces identified' in Armenia and believed to be related to active faulting are probably far too old to be radiocarbon dated.

Department of Geological Sciences, University of Durham,

Durham DH1 3LE, UK.

1. Cisternas, A. et al. Nature 339, 675-679 (1989)

2. Yegorkina, G. V. et al. Izv. Akad. Nauk. Fiz. Zemli 13, 554 562 (1977).

3. Maggs, W. W. Eos 70, 17 (1989)

4. Nikonov, A. A. Izv. Akad. Nauk, Fiz. Zemli 18, 713-725 (1982).

5. Borisov, B. A. Izv. Akad. Nauk, Fiz. Zemli 18, 726-737 (1982).

6. Ambraseys, N. N. \& Adams, R. D. Eos 70, 145-154 1989)

7. Westaway, R. Tectonics (submitted).

NATURE · VOL 341 · 28 SEPTEMBER 1989 